\title{
SISTEM PENDUKUNG KEPUTUSAN PEMILIHAN GURU TERBAIK DENGAN METODE ANALYTICAL HIERARCHY PROCESS DAN SIMPLE ADDITIVE WEIGHTING PADA IBTIDAIYAH HIKMATUSH SHOFWAH
}

\author{
Alvina Mirdania ${ }^{1}$, Nawindah ${ }^{2}$ \\ ${ }^{1,2}$ Fakultas Teknologi Informasi, Sistem Informasi, Universitas Budi Luhur, Jakarta Selatan, Indonesia \\ Email: ${ }^{1} 1612500734 @$ student.budiluhur.ac.id, ${ }^{2 *}$ Nawindah@ budiluhur.ac.id \\ (* : corresponding author)
}

\begin{abstract}
Abstrak-Sistem penunjang keputusan guru terbaik difokuskan, mempermudah dalam melakukan penilaian kinerja guru. Pada madrasah tersebut sering mengalami kesulitan pada proses rekapitulasi dan pengolahan data, kinerja guru yang hanya dilakukan dengan menggunakan absen manual dan belum menggunakan metode yang tepat untuk melakukan proses pemilihan guru terbaik. Oleh karena itu Madrasah Ibtidaiyah Hikmatush Shofwah memerlukan sistem penunjang keputusan untuk melakukan pemilihan guru terbaik guna meningkatkan kinerja guru untuk menjadi lebih baik lagi dalam proses belajar mengajar. Adapun metode yang digunakan yaitu analytical hierarchy process dan simple additive weighting Hasil yang didapatkan dapat mengurangi kesalahan dalam penilaian kinerja guru. Pada prinsipnya metode analytical hierarchy process akan memecahkan persoalan dengan 3 cara yaitu: menyusun hirarki, menentukan prioritas dan mengukur konsistensi. Sedangkan metode simple additive weighting akan mencari penjumlahan terbobot dari rating kinerja setiap alternatif untuk semua atribut. Kriteria yang dinilai dalam penentuan guru terbaik antara lain: nilai SKP, perilaku memiliki sub kriteria orientasi pelayanan, integritas, komitmen, disiplin, kerjasama dan kepribadian. Hasil pengujian sistem pada semua kriteria dan sub kriteria terhadap 5 orang guru yang dinilai, menghasilkan peringkat pertama dengan nilai tertinggi sebesar 0.9975.
\end{abstract}

Kata Kunci: Sistem penunjang keputusan, analytical hierarchy process, simple additive weighting, pemilihan guru, pemilihan guru terbaik

\begin{abstract}
The best decision support system makes it easier to assess teacher performance. In these madrasas, they often experience difficulties in the process of recapitulation and data processing, teacher performance is only done using manual absences and have not used the right method to carry out the process of selecting the best teacher. Therefore, Madrasah Ibtidaiyah Hikmatush Shofwah requires a decision support system for selecting teachers in order to improve teacher performance to become even better in the teaching and learning process. The method used is analytical hierarchical process and simple additive weighting results that can reduce errors in teacher performance measurement. In principle, the analytical hierarchical process method will solve problems in 3 ways, namely: arranging a hierarchy, determining priorities and measuring consistency. Meanwhile, the simple additive weighting method will look for the weighted sum of the performance ratings of each alternative for all attributes. The criteria for determining teachers include: SKP scores, behavior that has criteria of orientation, integrity, commitment, discipline, cooperation and personality. The results of the system on all the criteria and sub-criteria for 5 teachers who left, ranked first with an examiner score of 0.9975.
\end{abstract}

Keywords: Decision support system, analytical hierarchy process, simple additive weighting, selection teacher, selection of the best teachers

\section{PENDAhuluan}

Peran guru dalam proses pendidikan sangatlah penting, hal ini merupakan faktor utama dalam terciptanya generasi penerus bangsa yang berkualitas. Oleh karena itu peran dan kemampuan para pendidik sangat penting dalam mengubah karakter generasi penerus untuk menjadi generasi maju, selain itu dapat meningkatkan mutu pendidikan nasional. Berdasarkan undang-undang nomor 14 tahun 2005 menyebutkan bahwa guru adalah pendidik profesional dengan tugas utama mendidik, mengajar, membimbing, mengarahkan, melatih dan mengevaluasi peserta didik pada pendidikan anak usia dini jalur pendidikan formal, pendidikan dasar, dan pendidikan menengah [1]. Madrasah Ibtidaiyah Hikmatush Shofwah yang berada di Tangerang ini merupakan sekolah yang berupaya meningkatkan mutu pendidikannya. Perlunya meningkatkan sumber daya dalam hal mengajar siswa dan mendapatkan ilmu yang bermanfaat dengan peran guru yang berprestasi [2].

Proses pemilihan guru terbaik masih bersifat subjektif [3]. Salah satunya dengan meningkatkan kualitas guru dan memberikan aspirasi kepada guru terbaik. Hal ini dilakukan dengan tujuan agar setiap guru memiliki motivasi dan semangat agar dapat menjadi guru terbaik. Beberapa penelitian yang pernah dilakukan diantaranya: penentuan guru berprestasi dalam meningkatkan kompetensi diperlukan sebuah penilaian untuk kinerja guru dengan menggunakan Fuzzy AHP yang memiliki akurasi 82, 501\% [4], pemilihan guru berprestasi sangat 
memadai dan dapat membantu sekolah dalam mengambil keputusan yang relevan [5] dengan tidak adanya kesenjangan dengan perbedaan status [6] sehingga institusi dapat memberikan reward [7].

Pada Penelitian sebelumnya oleh [8] yang dibuat untuk pemilihan kinerja guru berprestasi mencari metode yang lebih baik dengan hasil sama dengan nilai 0,913, pemilihan guru berprestasi dengan kondisi awal menggunakan voting yang dapat menimbulkan kecemburuan sosial kemudian dilakukan dengan menggunakan metode SAW untuk mendapatkan bobot dari rating kinerja guru yang ada dengan kriteria: kinerja guru, absensi guru, wawasan guru, tanggung jawab guru, dan cara mengajar guru dengan hasil Elie Sundary,S.pd sebagai guru berprestasi [9], akurasi keputusan untuk pemilihan guru berprestasi menggunakan metode Simple Additive Weighting (SAW), kriteria yang digunakan adalah kualifikasi pendidikan, disiplin, kerapihan, akhlak, kepribadian dan cara mengajar dan tingkat akurasi yang didapatkan memiliki persentase $80 \%$ dengan akurat, cepat dan objektif [10].

Penelitian lainnya oleh [11], seleksi guru terbaik dengan Additive Weighting (SAW) guna mencari bobot pada alternatif terpilih, kriteria yang digunakan: pendidikan, keahlian, kedisiplinan, jabatan, jarak menuju sekolah, pengalaman kerja dengan hasil kemudahan dalam efisiensi waktu dan biaya dalam mencari guru terbaik.

Penelitian oleh [12] dengan pemilihan dosen berprestasi dengan menggunakan metode Simple Additive Weighting (SAW) guna mendapatkan hasil terbaik dalam meningkatkan kualitas dosen dengan kriteria: pendidikan, jabatan akademi, jumlah sertifikat dan lama mengajar dengan hasil konsisten. Data dosen yang digunakan dalam penelitian sebanyak 20 dosen, dengan hasil alternatif terpilih A13 dengan nilai 14,4.

Pada Madrasah Ibtidaiyah Hikmatush Shofwah sering mengalami kesulitan pada proses rekapitulasi dan pengolahan data, kinerja guru yang hanya dilakukan dengan menggunakan absen manual dan belum menggunakan metode yang tepat untuk melakukan proses pemilihan guru terbaik. Oleh karena itu Madrasah Ibtidaiyah Hikmatush Shofwah memerlukan sistem penunjang keputusan untuk melakukan pemilihan guru terbaik guna meningkatkan kinerja guru untuk menjadi lebih baik lagi dalam proses belajar mengajar.

Berdasarkan uraian diatas maka perlu dibangun sistem penunjang keputusan untuk membantu pemilihan guru terbaik dengan menggunakan metode analytical hierarchy process (AHP) dalam menentukan bobot kriteria karena belum adanya pembobotan dalam setiap kriteria serta menggunakan metode simple additive weighting (SAW) untuk melakukan perhitungan yang akan menghasilkan nilai terbesar untuk alternatif guru terbaik.

\section{METODE PENELITIAN}

Metode penelitian yang digunakan dalam penelitian ini adalah Analytical Hierarchy Process (AHP) dan Simple Additive Weighting (SAW). Metode Analytical Hierarchy Process (AHP) digunakan untuk menentukan prioritas dari beberapa kriteria dengan melakukan analisis berpasangan dari masing-masing kriteria.Simple additive weighting digunakan untuk menentukan nilai kriteria terpilih [13].

\subsection{Analytical Hierarchy Process}

Metode analytical hierarchy process (AHP) yang dikembangkan oleh Thomas L Saaty , mengatakan bahwa AHP berfungsi untuk memecahkan masalah yang kompleks menjadi sub-sub masalah lalu menyusunnya ke dalam bentuk hierarchy[14]. Pengujian model AHP dilakukan dengan cara menghitung nilai consistency index (CI) dan nilai consistency ratio $\mathrm{CR}$ ) yaitu:

a. Perhitungan consistency index (CI), pengukuran ini dimaksudkan agar dapat diketahui konsistensi jawaban yang akan berpengaruh kepada kesahan hasil. Dapat dilihat pada rumus (1) berikut ini :

$$
C I=\frac{\lambda \cdot M a x-n}{n-1}
$$

keterangan :

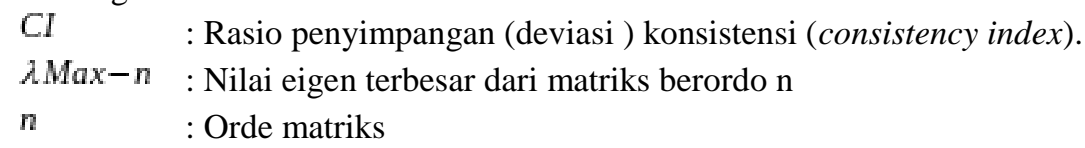

Untuk mengetahui CI dengan besaran tertentu cukup baik atau tidak, maka perlu diketahui Consistency Ratio $(\mathrm{CR})$ yang dianggap baik, yaitu apabila $\mathrm{CR} \approx 0,1$.

b. Perhitungan untuk menghitung banyaknya alternatif, dapat dilihat pada rumus (2) :

$$
C I=\frac{(\pi-n)}{n-1} n
$$

c. Perhitungan Consistency Ratio (CR) 
Available online at http://jom.fti.budiluhur.ac.id/index.php/IDEALIS/index

Consistency Ratio merupakan parameter yang digunakan untuk memeriksa perbandingan berpasangan telah dilakukan dengan konsekuen atau tidak. Untuk consistency ratio dapat dilihat pada rumus (3) :

$C R=\frac{C l}{R I}$

Keterangan :

CR : Rasio konsistensi

$R I$ : Index Random

Nilai random index merupakan nilai $R I$ yang dikeluarkan oleh Oarkridge laboratory yang berupa Tabel 1 seperti terlihat berikut ini [6]:

Tabel 1. Nilai random index (Oarkridge laboratory)

\begin{tabular}{cc}
\hline $\mathrm{N}$ & $\mathrm{RI}$ \\
\hline 1 & 0,00 \\
2 & 0,00 \\
3 & 0,58 \\
4 & 0,90 \\
5 & 1,12 \\
6 & 1,24 \\
7 & 1,32 \\
8 & 1,41 \\
9 & 1,45 \\
10 & 1,49 \\
11 & 1,51 \\
12 & 1,48 \\
13 & 1,56
\end{tabular}

Dari Tabel 1 dapat dilihat nilai $\mathrm{N}=1 \overline{\text { memiliki nilai } \mathrm{RI}=0,00}$, nilai $\mathrm{N}=2$ maka $\mathrm{RI}=0,00$, nilai $\mathrm{N}=3$ maka $\mathrm{RI}=0,58$ dan seterusnya sampai dengan nilai $\mathrm{N}=13$ maka $\mathrm{RI}=1,58$.

\subsection{Simple Additive Weighting}

Metode simple additive weighting (SAW) membutuhkan proses normalisasi matriks keputusan (X) ke suatu skala yang dapat dibandingkan dengan semua rating alternatif yang ada [15]. Untuk melakukan perhitungannya dapat dilihat pada rumus (4) dan (5) berikut ini :

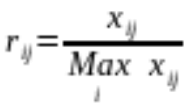

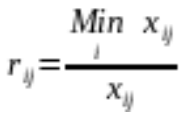

Keterangan :

Rumus (4) : : jika j merupakan atribut keuntungan (benefit).

Rumus (5) : jika j adalah atribut biaya (cost).

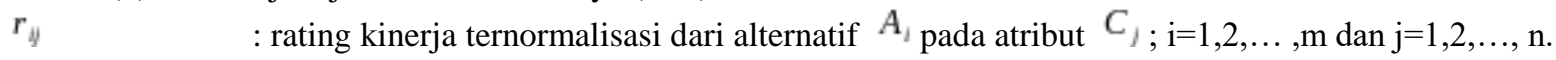
Untuk nilai preferensi setiap alternatif dapat dilihat pada rumus (6) berikut ini :

$$
V_{i}=\sum_{j=1}^{n} w_{j} r_{i j}
$$

Keterangan :

$$
\begin{array}{ll}
V_{i} & \text { : rank untuk setiap alternatif. } \\
W_{d} & \text { : nilai bobot dari setiap kriteria. }
\end{array}
$$

Hasil akhir diperoleh dari proses perangkingan yaitu penjumlahan dari perkalian matriks ternormalisasi $\mathrm{R}$ dengan vektor bobot sehingga diperoleh nilai terbesar yang dipilih sebagai nilai alternatif terbaik sebagai solusi. Adapun langkah yang digunakan pada metode SAW adalah: 
Available online at http://jom.fti.budiluhur.ac.id/index.php/IDEALIS/index

a. Menentukan kriteria yang dijadikan acuan pengambilan keputusan.

b. Menentukan kriteria-kriteria yang akan dijadikan acuan dalam pengambilan keputusan, yaitu $C_{\mathbb{d}}$.

c. Menentukan nilai bobot dari masing-masing kriteria.

d. Menentukan rating kecocokan setiap alternatif pada setiap kriteria.

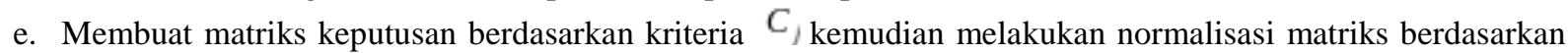
persamaan yang disesuaikan dengan jenis atribut (atribut keuntungan maupun atribut biaya) sehingga diperoleh matriks ternormalisasi R.

f. Memberikan nilai preferensi untuk setiap alternatif $V_{u}$.

\section{HASIL DAN PEMBAHASAN}

Hasil dan pembahasan untuk sistem pendukung keputusan pemilihan guru terbaik dengan metode AHP dan SAW diuraikan sebagai berikut:

\subsection{Analisa dan Perancangan}

Pada Gambar 1 dalam use case diagram input penilaian guru terbaik, dengan beberapa kegiatan yang dilakukan yaitu entri data guru, data kriteria dan data sub kriteria. Kegiatan tersebut dilakukan oleh tata usaha sekolah yang bertugas, dapat dilihat pada gambar 1 berikut ini :

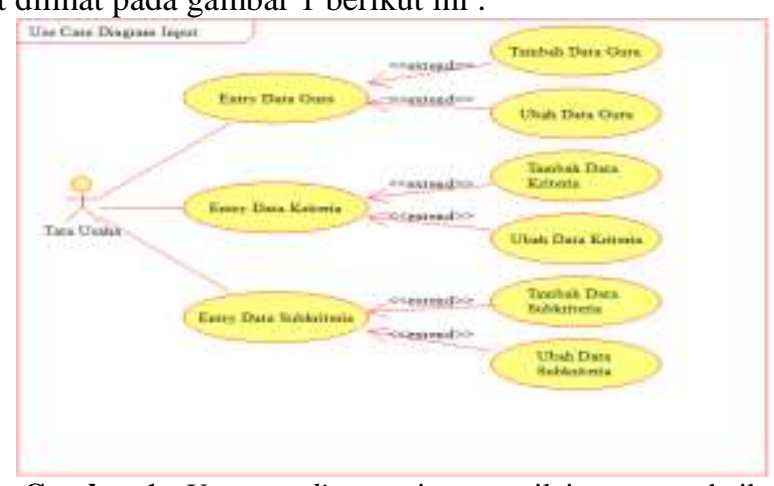

Gambar 1. Use case diagram input penilaian guru terbaik

Pada Gambar 1 menggambarkan entry data guru, entry data kriteria dan entry data subkriteria yang akan di olah untuk proses penilaian AHP dan juga SAW untuk menghasilkan data nilai guru terbaik. Berikut ini hirarki pemilihan guru terbaik dapat dilihat pada Gambar 2:

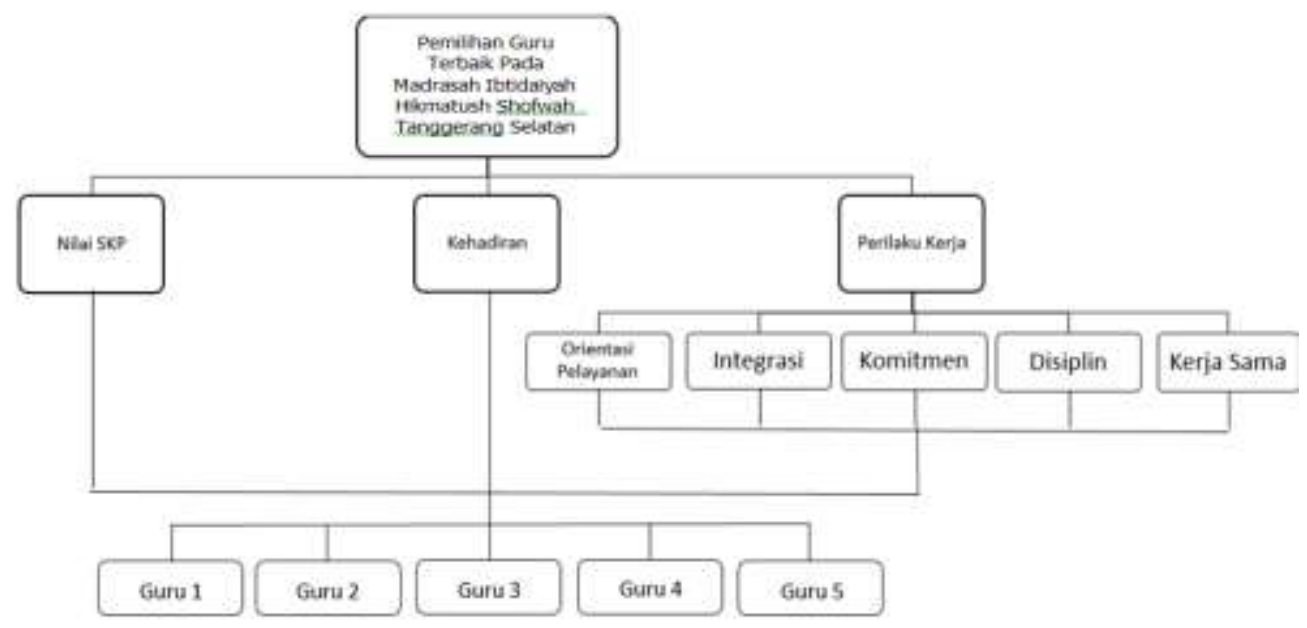

Gambar 2. Hirarki Pemilihan Guru Terbaik

Goal atau tujuan dari struktur hirarki yang terdapat pada gambar 2 pemilihan guru terbaik, berdasarkan kriteria dan sub kriteria yang ada akan dilakukan perbandingan berpasangan antar kriteria-kriterianya sehingga akan diperoleh bobot kriteria-kriterianya. Identifikasi kriteria nilai SKP, kehadiran, perilaku kerja.Identifikasi sub kriteria orientasi pelayanan, integritas, komitmen, disiplin, kerjasama.Adapun identifikasi alternatif yang 
akan dinilai kinerjanya berdasarkan kriteria yang telah ditetapkan, 5 orang dijadikan sebagai alternatif yaitu Nurul Hikmah, S.Pd, Rohani, S.Pd ,Nara, S.Pd ,Sulaiman, S.Pd dan Abdullah Yunus, S.Pd.I Untuk logical record structure terdiri dari beberapa tabel yaitu guru, punya, kriteria, banding, subkriteria, banding2, hasil kinerja, punya 2 terlihat pada Gambar 3 , yaitu :

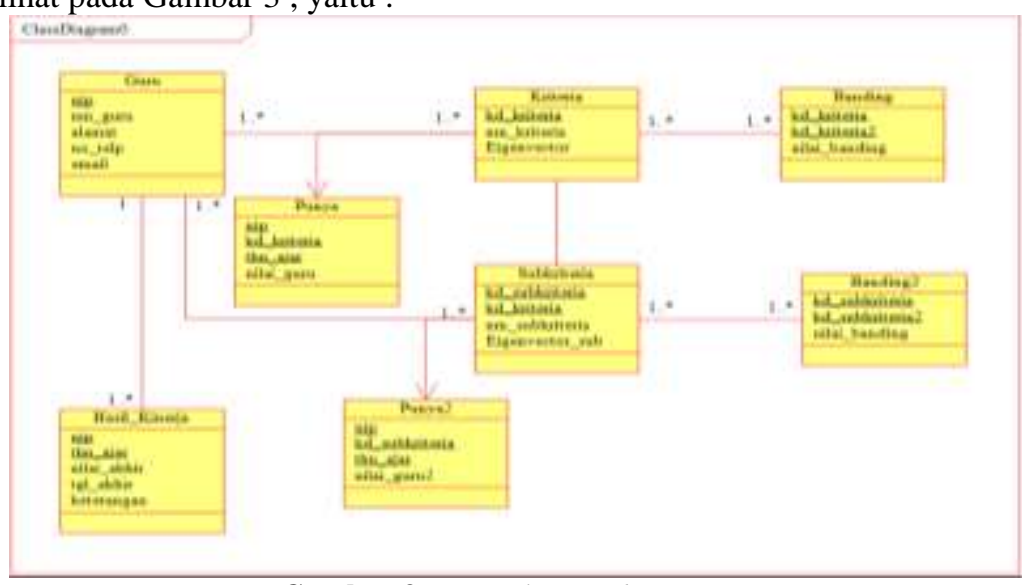

Gambar 3. Logical Record Structure

Pada Gambar 3 terlihat tabel yang digunakan saling berelasi untuk tabel guru berelasi dengan tabel kriteria, tabel punya, tabel sub kriteria dan tabel hasil kerja, diikuti dengan relasi dengan tabel-tabel lainnya.

\subsection{Analisa dan Perancangan}

Dari hasil kuesioner yang sudah diisi oleh Wakasek kurikulum maka didapatkan tingkat perbandingan antar kriteria yaitu kriteria nilai SKP,perilaku, dan kehadiran memiliki nilai perbandingan kepentingan antar kriteria yaitu :

a. Nilai SKP 3 (tiga) kali lebih penting dari perilaku.

b. Nilai SKP 5 (lima) kali lebih penting dari kehadiran.

c. Perilaku 4 (empat) kali lebih penting dari kehadiran.

Adapun sub kriteria orientasi pelayanan, integritas, komitmen, disiplin, kerjasama memiliki nilai perbandingan kepentingan antar sub kriteria yaitu:

a. Orientasi pelayanan 7 (tujuh) kali lebih penting dari integritas.

b. Orientasi pelayanan 2 (dua) kali lebih penting dari komitmen.

c. Orientasi pelayanan 4 (empat) kali lebih penting dari disiplin.

d. Orientasi pelayanan 4 (empat) kali lebih penting dari kerja sama.

e. Komitmen 5 (lima) kali lebih penting dari integritas.

f. Disiplin 3 (tiga) kali lebih penting dari integritas.

g. Integritas sama penting dengan kerja sama.

h. Komitmen 5 (lima) kali lebih penting dari disiplin.

i. Komitmen 4 (empat) kali lebih penting dari kerja sama.

j. Kerja sama 2 (dua) kali lebih penting dari disiplin.

Perbandingan kepentingan antar kriteria,berdasarkan kuesioner yang telah diajukan kepada responden maka didapat tabel matriks tersaji pada tabel 2 , yaitu :

Tabel 2. Matriks Perbandingan Kriteria

\begin{tabular}{cccc}
\hline Kriteria & Nilai SKP & Perlilaku & Kehadiran \\
\hline Nilai SKP & $1 / 1$ & $3 / 1$ & $5 / 1$ \\
Perilaku & $1 / 3$ & $1 / 1$ & $4 / 1$ \\
Kehadiran & $1 / 5$ & $1 / 4$ & $1 / 1$
\end{tabular}

Nilai yang ada pada tabel 2 kemudian diolah dengan beberapa langkah sebagai berikut:

a. Mengubah data pecahan pada tabel 2 menjadi data desimal, sebagai berikut :
$[1,0000 \quad 3,0000 \quad 5,0000]$
$0,3333 \quad 1,0000 \quad 4,0000$
$0,2000 \quad 0,2500 \quad 1,0000$ 
Available online at http://jom.fti.budiluhur.ac.id/index.php/IDEALIS/index

b. Mengalikan matriks dengan dirinya sendiri (iterasi 1 ) sebagai berikut :

$\left[\begin{array}{lll}1,0000 & 3,0000 & 5,0000 \\ 0,3333 & 1,0000 & 4,0000 \\ 0,2000 & 0,2500 & 1,0000\end{array}\right] \times\left[\begin{array}{lll}1,0000 & 3,0000 & 5,0000 \\ 0,3333 & 1,0000 & 4,0000 \\ 0,2000 & 0,2500 & 1,0000\end{array}\right]$

c. Menjumlahkan setiap baris hasil dari perkalian matriks iterasi ke 1:

$\left[\begin{array}{ccc}2,9999 & 7,2500 & 22,0000 \\ 1,4666 & 2,9999 & 9,6665 \\ 0,4833 & 1,1000 & 3,0000\end{array}\right]$

d. Menormalisasikan dengan membagi tiap-tiap jumlah baris pada matriks dengan total baris yang akan menghasilkan eigenvector iterasi ke 1 :

$\frac{\left[\begin{array}{c}32,2499 \\ 14,1330 \\ 4,5833\end{array}\right]}{50,9662}$

e. Menormalisasikan dengan membagi tiap-tiap jumlah baris pada matriks dengan total yang akan menghasilkan eigen vector iterasi ke 1 :

$\frac{\left[\begin{array}{c}32,2499 \\ 14,1330 \\ 4,5833\end{array}\right]}{50,9662}=\frac{\left[\begin{array}{l}0,6327 \\ 0,2773 \\ 0,0900\end{array}\right]}{1,0000}$

Untuk tingkat perbandingan antar sub kriteria dapat dilihat pada Tabel 3 berikut in:

Tabel 3. Perbandingan Kepentingan Antar Sub Kriteria

\begin{tabular}{lccccc}
\hline Kriteria & $\begin{array}{l}\text { Orientasi } \\
\text { Pelayanan }\end{array}$ & Integritas & Komitmen & Disiplin & $\begin{array}{c}\text { Kerja } \\
\text { sama }\end{array}$ \\
\hline $\begin{array}{l}\text { Orientasi } \\
\text { pelayanan }\end{array}$ & $1 / 1$ & $7 / 1$ & $2 / 1$ & $4 / 1$ & $4 / 1$ \\
Integritas & $1 / 7$ & $1 / 1$ & $1 / 5$ & $1 / 3$ & $1 / 1$ \\
Komitmen & $1 / 2$ & $5 / 1$ & $1 / 1$ & $5 / 1$ & $4 / 1$ \\
Disiplin & $1 / 4$ & $3 / 1$ & $1 / 5$ & $1 / 1$ & $1 / 2$ \\
Kerja sama & $1 / 4$ & $1 / 1$ & $1 / 4$ & $2 / 1$ & $1 / 1$ \\
\hline
\end{tabular}

Pada Tabel 3 terlihat beberapa kriteria yang digunakan yaitu orientasi pelayanan, integritas, komitmen, disiplin dan kerja sama. Berdasarkan tabel 3 maka langkah yang dilakukan yaitu mencari nilai eigen vector dengan tahapan sebagai berikut:

a. Mengubah data pecahan pada tabel 3 menjadi bentuk desimal sebagai berikut :

$\left[\begin{array}{lllll}1,0000 & 7,0000 & 2,0000 & 4,0000 & 4,0000 \\ 0,1429 & 1,0000 & 0,2000 & 0,3333 & 1,0000 \\ 0,5000 & 5,0000 & 1,0000 & 5,0000 & 4,0000 \\ 0,2500 & 3,0000 & 0,2000 & 1,0000 & 0,5000 \\ 0,2500 & 1,0000 & 0,2500 & 2,0000 & 1,0000\end{array}\right]$

b. Mengalikan matriks dengan dirinya sendiri iterasi 1 sebagai berikut :

$\left[\begin{array}{lllll}1,0000 & 7,0000 & 2,0000 & 4,0000 & 4,0000 \\ 0,1429 & 1,0000 & 0,2000 & 0,3333 & 1,0000 \\ 0,5000 & 5,0000 & 1,0000 & 5,0000 & 4,0000 \\ 0,2500 & 3,0000 & 0,2000 & 1,0000 & 0,5000 \\ 0,2500 & 1,0000 & 0,2500 & 2,0000 & 1,0000\end{array}\right] \times\left[\begin{array}{ccccc}1,0000 & 7,0000 & 2,0000 & 4,0000 & 4,0000 \\ 0,1429 & 1,0000 & 0,2000 & 0,3333 & 1,0000 \\ 0,5000 & 5,0000 & 1,0000 & 5,0000 & 4,0000 \\ 0,2500 & 3,0000 & 0,2000 & 1,0000 & 0,5000 \\ 0,2500 & 1,0000 & 0,2500 & 2,0000 & 1,0000\end{array}\right]$


Available online at http://jom.fti.budiluhur.ac.id/index.php/IDEALIS/index

c. Hasil perkalian matriks iterasi 1 sebagai berikut :

$\left[\begin{array}{ccccc}5,0003 & 40,0000 & 7,2000 & 28,3331 & 25,0000 \\ 0,7191 & 5,0002 & 1,0025 & 4,2382 & 3,5383 \\ 3,9645 & 32,5002 & 5,0000 & 21,6665 & 17,5000 \\ 1,1537 & 9,2500 & 1,6250 & 4,9999 & 5,8000 \\ 1,2679 & 11_{x}, 0000 & 1,6000 & 6,5833 & 5,0000\end{array}\right]$

d. Menjumlahkan setiap baris hasil dari perkalian matriks iterasi ke 1, sebagai berikut :

$\frac{\left[\begin{array}{c}32,2499 \\ 14,1330 \\ 4,5833\end{array}\right]}{50,9662}$

e. Melakukan normalisasi dengan membagi tiap-tiap jumlah baris pada matriks dengan total baris yang akan menghasilkan eigen vector iterasi ke 1

$\frac{\left[\begin{array}{c}105,5334 \\ 14,4983 \\ 80,6310 \\ 22,8286 \\ 25,4512\end{array}\right]}{248,9425} \Rightarrow \frac{\left[\begin{array}{l}0,4240 \\ 0,0582 \\ 0,3239 \\ 0,0917 \\ 0,1022\end{array}\right]}{1,0000}$

\subsection{Pengujian Metode Analytical Hierarchy Process (AHP) Untuk Kriteria}

Pengujian model AHP dilakukan dengan cara menghitung nilai Consistency Index (CI) dan nilai Consistency Ratio (CR) dengan langkah sebagai berikut:

a. Mengalikan nilai bilangan desimal dari setiap matriks kriteria dengan eigenvector, sebagai berikut :

$\left[\begin{array}{lll}1,0000 & 3,0000 & 5,0000 \\ 0,3333 & 1,0000 & 4,0000 \\ 0,2000 & 0,2500 & 1,0000\end{array}\right] \times\left[\begin{array}{l}0,6327 \\ 0,2773 \\ 0,0900\end{array}\right]$

Sehingga menghasilkan: nilai $\mathrm{SKP}=1,9146$, perilaku $=0,8482$, ehadiran $=0,2859$

b. Menghitung consistency vector dengan cara menentukan nilai rata-rata yaitu membagi hasil dari perhitungan sebelumnya dengan hasil eigen vector iterasi ke 2 (Weighted Sum Vector), sebagai berikut :

$$
\begin{aligned}
& 1,9146 / 0,6327=3,0260 \\
& 0,8482 / 0,2773=3,0587 \\
& 0,2859 / 0,0900=3,1766
\end{aligned}
$$

c. Menghitung nilai rata-rata dari Consistency vector, sebagai berikut :

$$
n=\frac{3,0260+3,0587+3,1766}{3}=3,0871
$$

d. Menghitung nilai consistency index (CI) dengan menggunakan rumus (2), sebagai berikut :

$$
C I=\frac{(3,0871-3)}{3-1}=0,0435
$$

e. Menghitung consistency ratio (CR), dibutuhkan nilai random index (RI) yang didapat dari tabel 1 dengan menggunakan rumus (3) sebagai berikut :

$$
C R=\frac{0,0435}{0,58}=0,0750
$$

Dari hasil perhitungan maka didapatlah nilai CR yaitu sebesar 0,0750. Penilaian perbandingan dikatakan konsisten jika nilai CR tidak lebih besar dari 0,10. Sehingga penilaian perbandingan kriteria pemilihan guru terbaik tidak perlu dilakukan perhitungan ulang.

\subsection{Pengujian Metode Analytical Hierarchy Process (AHP) Untuk Sub Kriteria}

Pengujian model AHP dilakukan dengan cara menghitung nilai consistency index (CI) dan nilai consistency ratio (CR), adapun tahapan yang diperlukan sebagai berikut:

a. Mengalikan nilai bilangan desimal dari setiap matriks sub kriteria dengan eigenvector. 
Available online at http://jom.fti.budiluhur.ac.id/index.php/IDEALIS/index

$\left[\begin{array}{lllll}1,0000 & 7,0000 & 2,0000 & 4,0000 & 4,0000 \\ 0,1429 & 1,0000 & 0,2000 & 0,3333 & 1,0000 \\ 0,5000 & 5,0000 & 1,0000 & 5,0000 & 4,0000 \\ 0,2500 & 3,0000 & 0,2000 & 1,0000 & 0,5000 \\ 0,2500 & 1,0000 & 0,2500 & 2,0000 & 1,0000\end{array}\right] \times\left[\begin{array}{l}0,4240 \\ 0,0582 \\ 0,3239 \\ 0,0917 \\ 0,1022\end{array}\right]=\left[\begin{array}{l}2,2548 \\ 0,3163 \\ 1,6942 \\ 0,4882 \\ 0,5308\end{array}\right]$

Dari perhitungan maka dapat didapatkan hasil untuk sub kriteria orientasi pelayanan $=2,2548$, integritas $=0,3163$, komitmen $=1,6942$, disiplin $=0,4882$, kerja sama $=0,5308$.

b. Menghitung consistency vector dengan cara menentukan nilai rata-rata yaitu membagi hasil dari perhitungan sebelumnya dengan hasil eigenvector iterasi ke 2 (Weighted Sum Vector).

$$
\begin{aligned}
& 2,2548 / 0,4240=5,3180 \\
& 0,3163 / 0,0582=5,4347 \\
& 1,6942 / 0,3239=5,2306 \\
& 0,4882 / 0,0917=5,3238 \\
& 0,5308 / 0,1022=5,1937
\end{aligned}
$$

c. Menghitung nilai rata-rata dari consistency vector.

$$
x=\frac{(5,3180+5,4347+5,2306+5,3238+5,1937)}{5}=5,3001
$$

d. Menghitung nilai consistency index (CI) dengan menggunakan rumus (2), untuk perhitungannya sebagai berikut :

$$
C I=\frac{(5,3001-5)}{5-1}=0,0750
$$

e. Menghitung consistency ratio (CR), dibutuhkan nilai random index (RI) yang didapat dari tabel 1, dengan perhitungan menggunakan rumus (3) sebagai berikut :

$$
C R=\frac{0,0750}{1,12}=0,0670
$$

Dari hasil perhitungan maka didapatlah nilai CR yaitu sebesar 0,0670. Penilaian perbandingan dikatakan konsisten jika nilai CR tidak lebih besar dari 0,10 . Sehingga penilaian perbandingan sub kriteria pemilihan guru terbaik tidak perlu dilakukan perhitungan ulang.

\subsection{Model Keputusan Dengan Simple Additive Weighting}

Adapun bobot kriteria dan sub kriteria yang digunakan berdasarkan hasil perhitungan sebagai berikut: persentase bobot Nilai SKP 63.27\%, kehadiran 27.73\%, perilaku 9.00\%. Adapun persentase bobot sub kriteria adalah orientasi pelayanan $42.40 \%$, integritas $5.82 \%$, komitmen $32.39 \%$, disiplin $9.17 \%$, kerjasama $10.22 \%$.

\subsection{Matriks dan Hasil Peringkat}

Berdasarkan banyaknya guru pada Madrasah Ibtidaiyah Hikmatush Shofwah Tangerang Selatan, maka diambil 5 (lima) guru sebagai contoh untuk penerapan dengan metode simple additive weighting (SAW) dalam penentuan guru terbaik, maka dapat dilihat data alternatif dalam bentuk matriks $\boldsymbol{r}_{\text {i }}$ berikut ini:

$r_{4}=\left[\begin{array}{lllllll}84,00 & 86,50 & 83,00 & 83,00 & 91,00 & 82,00 & 81,00 \\ 83,80 & 95,00 & 83,00 & 82,00 & 91,00 & 83,00 & 80,00 \\ 83,40 & 95,00 & 82,00 & 82,00 & 90,00 & 81,00 & 82,00 \\ 82,20 & 95,00 & 80,00 & 80,00 & 91,00 & 81,00 & 79,00 \\ 81,00 & 95,00 & 78,00 & 79,00 & 91,00 & 79,00 & 78,00\end{array}\right]$

Perlunya dilakukan perhitungan tiap kriteria sehingga diperoleh nilai dari masing-masing alternatif dengan menggunakan rumus (4) sebagai berikut:

$$
R_{11}=\frac{84,00}{\max 84_{2}, 00 ; 83,80 ; 83,40 ; 82,20 ; 81 ; 00}=\frac{84,00}{84_{2}, 00}
$$

R11 memiliki nilai 1, untuk perhitungan dengan cara yang sama dilakukan sampai dengan data terakhir sehingga didapatkan data pada tabel 4 dan tabel 5 berikut ini : 
Available online at http://jom.fti.budiluhur.ac.id/index.php/IDEALIS/index

Tabel 4. Nilai Matriks Normalisasi Sub Kriteria Perilaku Kerja

\begin{tabular}{lccccc}
\hline \multirow{2}{*}{ Alternatif } & \multicolumn{5}{c}{ Sub kriteria } \\
\cline { 2 - 6 } & $\begin{array}{l}\text { Orientasi } \\
\text { Pelayanan }\end{array}$ & Integritas & Komitmen & Disiplin & Kerja sama \\
\hline Nara & 1 & 1 & 1 & 0.9879 & 0,9878 \\
Nurul & 1 & 0.9879 & 1 & 1 & 0.9756 \\
Sulaiman & 0.9879 & 0.9879 & 0.9890 & 0.9759 & 1 \\
Rohani & 0.9638 & 0.9638 & 0.9638 & 1 & 0.9759 \\
Abdullah & 0.9397 & 0.9397 & 0.9518 & 1 & 0.9518 \\
\hline Bobot & 0.4240 & 0.0582 & 0.3239 & 0.0917 & 0.1022 \\
\hline
\end{tabular}

Data kriteria perilaku kerja dengan sub kriteria orientasi pelayanan, integritas, komitmen, disiplin dan kerja sama terlihat ada data yang nilainya sama dan berbeda.

Tabel 5. Nilai Matriks Normalisasi Kriteria

\begin{tabular}{lccc}
\hline Kriteria & Nilai SKP & Perilaku kerja & Kehadiran \\
\hline Nurul & 1 & 0,9975 & 0,9105 \\
Rohani & 0,9976 & 0,9967 & 1 \\
Nara & 0,9928 & 0,9981 & 1 \\
Sulaiman & 0,9785 & 0,9763 & 1 \\
Abdullah & 0,9642 & 0,9620 & 1 \\
\hline
\end{tabular}

Setelah ditemukan matriks normalisasi kriteria nilai SKP, perilaku kerja dan kehadiran ,dilanjutkan dengan menghitung hasil perangkingan nilai dengan menggunakan rumus 6 , sebagai berikut pada tabel 6 berikut ini :

Tabel 6. Hasil peringkat nilai

\begin{tabular}{lcc}
\hline Kriteria & Nilai SKP & Perilaku kerja \\
\hline Nara & 1 & 0,9975 \\
Nurul & 0,9976 & 0,9967 \\
Sulaiman & 0,9928 & 0,9981 \\
Rohani & 0,9785 & 0,9763 \\
Abdullah & 0,9642 & 0,9620 \\
\hline
\end{tabular}

Sehingga dapat disimpulkan bahwa nilai terbesar diperoleh oleh Nurul Hikmah, S.Pd sebagai alternatif terbaik dengan nilai 0.9975

\section{KESIMPULAN}

Berdasarkan hasil dan pembahasan yang telah dilakukan maka dapat diambil kesimpulan sebagai berikut: dengan adanya sistem pendukung keputusan menggunakan metode analytical hierarchy process dan simple additive weighting ini, mengurangi kesalahan penilaian kinerja terhadap guru yang ada di sekolah., mengurangi kesalahan dalam penilaian kinerja terhadap guru yang ada di sekolah. Terlihat Nurul Hikmah, S.Pd adalah guru terbaik dengan jumlah nilai 0,9975. Hal ini dapat dilihat dari hasil pengujian yang telah dilakukan. Dapat dilakukan penelitian lanjutan metode lainnya sehingga dapat membandingkan metode terbaik.

\section{DAFTAR PUSTAKA}

[1] P. D. Nasional, "UU 14-2005 Guru dan Dosen." P. 50, 2005, [Online]. Available: ttps://ppg.kemdikbud.go.id/download/undang-undang-republik-indonesia-nomor-14-tahun-2005-tentang-guru-dandosen/.

[2] I. Wahyu, S. Suparni, and A. Baroqah P., "Sistem Pendukung Keputusan Pemberian Pinjaman Pada KOPWALI Tangerang Dengan Metode AHP dan SAW," IJCIT (Indonesian Journal on Computer and Information Technology), vol.5, no.1, pp. 21-30, 2019.

[3] T. Mufizar, "Sistem Pendukung Keputusan Pemilihan Dosen Berprestasi Di STMIK Tasikmalaya Menggunakan Metode Simple Additive Weighting (SAW)," CSRID (Computer Science Research and Its Development Journal), vol. 7, no. 3, p. 155, 2016.

[4] D. R. Bahari, E. Santoso, and S. Adinugroho, "Sistem Pendukung Keputusan Penentuan Guru Berprestasi Menggunakan Fuzzy-Analytic Hierarchy Process ( F-AHP ) ( Studi Kasus : SMA Brawijaya Smart School )," Jurnal Pengembangan Teknologi Informasi dan Ilmu Komputer, vol. 2, no. 5, pp. 2095-2101, 2018. 
[5] Gustinar and Sarjono, "Analisis Dan Perancangan Sistem Pendukung Keputusan Pemilihan Guru Berprestasi Dengan Metode Ahp (Analytic Hierarchy Proces) Pada SMKN 9 Muaro Jambi,” Jurnal Manajemen Sistem Informasi, vol. 3, no. 1, pp. 922-935, 2018.

[6] Sopiah, E. K. Putra, and A. I. Hadiana, "Sistem Pendukung Keputusan Rekomendasi Guru Tetap Berdasarkan Data Guru Honorer Berprestasi Menggunakan Metode Analytic Hierarchy Process (AHP) dan Simple Additive Weighting (SAW)," Seminar Nasional Teknologi dan Multimedia, 2017, pp. 79-84.

[7] S. Suryati, Z. Jauhari, "Pemilihan Guru Berprestasi Menggunakan DSS (Decision Support System) Dengan Metode FMADM (Fuzzy Multiple Attribute Decission Making) Dan SAW (Simple Additive Weighting), Jurnal Ilmiah Fifo, vol. X, no. 1, pp. 62-75, 2018.

[8] L. Yusuf, Rahmawati, and D. A. N. Wulandari, "Komparasi Metode Analitical Hierarchy Procces Dan Simple Additive Weigthing Dalam Pemilihan Kinerja Guru," Jurnal Infortech, vol.1, no.2, pp. 97-104, 2019.

[9] Y. E. Chintyari and T. Prihatin, "Implementasi Metode Simple Additive Weighting Untuk Pemilihan Guru Berprestasi Pada SMP Islam Pondok Duta," JITK (Jurnal Ilmu Pengetahuan dan Teknologi Komputer), vol. 3, no. 2, pp. 233-238, 2018

[10] W. Wahyudi, J. Santony, and G. W. Nurcahyo, "Akurasi Keputusan dalam Penentuan Guru Berprestasi Dengan Menggunakan Metode Simple Additive Weighting (Studi Kasus Sekolah Menengah Kejuruan Muhammadiyah Batam)," Jurnal Sistim Informasi dan Teknologi, vol. 2, no. 1, pp. 9-14, 2020.

[11] T. Hidayat, S.Kom, M. Kom, F. Widiyanto, and Y. K. Hasim, "Rancang Bangun Decision Support System Pemilihan Guru Terbaik Menggunakan Metode Simple Additive Weighting (SAW) (Studi Kasus : SMA Bhakti Pertiwi Kota Tangerang)," JUTIS (Journal of Informatics Engineering), vol. 5, no. 1, pp. 52-56, 2017.

[12] E. K. Nurhasanah, S. Abadi, and P. Sukamto, "Sistem Pendukung Keputusan Pemilihan Mahasiswa Berprestasi Dengan Metode Simple Additive Weighting-Sistem Pendukung Keputusan Pemilihan Mahasiswa Berprestasi Dengan Metode Simple Additive Weighting," TEKNOSAINS, vol. 7, no. 2, pp. 107-118, 2020.

[13] D. Anggoro and N. Nawindah, "Perbandingan Fuzzy AHP-SAW Dengan Fuzzy AHP-Vikor Untuk Meningkatkan Daya Serap Politeknik Terhadap Industri," Jurnal Ilmiah Teknologi Informasi Terapan, vol. 6, no. 1, pp. 1-10, 2019.

[14] T. L. Saaty, "Decision making with the analytic hierarchy process," Int. J. Services Sciences, vol. 1, no. 1, pp. 83-98, 2008. 